УДК: 658:338.1

DOI: 10.35340/2308-104X.2019.85-4-05

\author{
ВПЛИВ СУЧАСНИХ \\ ІНФОРМАЦІЙНИХ \\ ТЕХНОЛОГІЙ НА РОЗВИТОК \\ МАРКЕТИНГОВОї \\ ЛОГІСТИКИ
}

ГУРЕНКО А. В., кандидат економічних наук, доцент, Азовський морський інститут Національного університету «Одеська морська академія»

\section{INFLUENCE OF MODERN INFORMATION \\ TECHNOLOGIES ON THE DEVELOPMENT OF MARKETING LOGISTICS}

\author{
GURENKO A., \\ Candidate of Economic Sciences \\ Associate Professor, Azov Maritime \\ Institute National University \\ "Odessa Maritime Academy"
}

У статті досліджено сутність маркетингової логістики. Особливу увагу приділено розвитку маркетингової логістики в умовах поширення індустрії 4.0. Розкрито особливості функціонування маркетингових та логістичних систем в умовах масштабних иифрових змін. Визначено перспективи розвитку вітчизняних підприємств у нових умовах інформачійного середовища. Розкрито проблеми впровадження сучасних інформаційних технологій в економічі України.

Ключові слова: маркетингова логістика, інформаційні технології, принщипи взаємодіі, бази даних, задоволення споживачів, інтеграція бізнес-прочесів, індустрія 4.0.

В статье исследована сущность маркетинговой логистики. Особое внимание уделено развитию маркетинговой логистики в условиях индустрии 4.0. Раскрыты особенности функциионирования маркетинговых и логистических систем в условиях масштабных иифровых изменений. Определены перспективы развития отечественных предприятий в новых условиях информачионной среды. Раскрыты проблемы внедрения современных информационных технологий в экономике Украины.

Ключевые слова: маркетинговая логистика, информаџионные технологии, принципы взаимодействия, базы данных, удовлетворение потребителей, интеграция бизнес-прочессов, индустрия 4.0.

The article explores the essence of marketing logistics. Particular attention is paid to the development of marketing logistics in industry 4.0. The features of the functioning of marketing and logistics systems in conditions of large-scale digital changes are disclosed. The development prospects of domestic enterprises in the new conditions of the information environment are defined. The problems of the introduction of modern information technologies in the Ukrainian economy.

Key words: marketing logistics, information technology, interaction principles, databases, customer satisfaction, integration of business processes, industry 4.0. 
Постановка проблеми. Стрімкий розвиток інформаційних технологій посприяв появі бізнесу нового типу - електронного, що являє собою велику кількість компаній функціонуючих у цифровому форматі. Характерними рисами сучасного бізнесу $\epsilon$ швидкий обмін інформацією, здійснення комерційних транзакцій через інформаційні системи, передача великих даних у мережі Інтернет, використання Web-сервісів. Активна інтеграція бізнес-процесів, збільшення числа посередницьких компаній та PL-провайдерів підвищили значущість маркетингових та логістичних послуг в інфраструктурному розвитку цифрової економіки [8].

Актуальними стають питання переходу від управління окремими маркетинговими та логістичними операціями до комплексного управління бізнеспроцесами із застосуванням новітніх інформаційних технологій. У зв'язку із цим у системі управління формуються нові організаційно-функціональні завдання, що орієнтуються на забезпечення комплексної взаємодії економічних систем, оптимізацію та інтеграцію компонентів інформаційних систем, створення досконалої системи маркетингової логістики.

Проте багатофункціональність управлінських функцій у системі маркетингової логістики ускладнює інформаційний обмін між різноманітними системами та посилює протиріччя виробничо-технологічного, організаційноекономічного, соціально-культурного характеру. Розв'язання проблем інформаційного обміну стає можливим за умов провадження нових методів управління заснованих на сучасних цифрових технологіях [1], [7].

В Україні вже активно застосовуються новітні інформаційні технології, однак процедура інтеграції бізнес-процесів з традиційного формату до онлайнрежиму ще потребує дослідження та адаптації. Суттєвого значення набуває аналіз впливу інформаційних технологій на формування ефективної системи розподілу товарів, управління взаємовідносинами зі споживачами, управління портфелем замовлень та побудова сервісної політики [5].

Аналіз останніх досліджень $i$ публікаиій. На сьогоднішній день проблематика маркетингової логістики достатньо вивчається та обговорюється у науковому середовище. Дослідженню окремих питань маркетингової логістики присвячені роботи закордонних вчених П. Амстронга, М. Кристофера, Ф. Котлера, Р. Тейлора [3], [10], [11]. Окремі аспекти розвитку логістики представлено в працях Г.Платухи, А. Длігача, В. Скіцька, Є. Крикавського [2], [4], [6].

Сучасні тенденції розвитку маркетингової логістики в умовах цифрової економіки досліджено в працях В. Скіцька, М. Гурської та інших вітчизняних вчених [1], [7], [8]. Разом із цим деякі специфічні питання управління в системі збуту і маркетингу залишаються не розкритими у повній мірі. Потребують дослідження особливостей впливу новітніх технологій на розвиток маркетингової логістики.

Meта статmi. Незважаючи на те, що тематика цифрового формату маркетингової логістики розглядається у зарубіжних виданнях, в українському середовищі вона поки не отримала свого адаптивного розвитку. Метою статті $\epsilon$ розкриття особливостей впливу сучасних інформаційних технологій на розвиток маркетингової логістики. 
Виклад основного матеріалу дослідження. Сучасні концепцій логістики та маркетингу базуються на однакових цілях - задоволення потреб споживачів. Логістика орієнтована на задоволення потреб споживачів через ефективне управління матеріальними, інформаційними та іншими потоками. Маркетинг спрямований на раціональне управління виробництвом і реалізацію продукції 3 урахуванням потреб споживачів. В обох концепціях простежується чітко виражена роль споживача. Це поєднує у єдиний бізнес-процес логістику та маркетинг й орієнтує їх на оптимізацію потокових процесів, що виникають в процесі взаємодії підприємства 3 ринком. Одночасно поєднуються методи прогнозування, логістики, маркетингу, математичного моделювання та інших наук, це обумовлює розвиток маркетингової логістики [3], [4], [8].

Ключовими настановами маркетингової логістики є координація дій усіх учасників ринкових відносин і доведення товару до споживача з мінімальними витратами, в найкоротші строки. Реалізація намічених цілей ускладняється мінливістю ринкового середовища, що підштовхує до перегляду низки завдань на мікро- і мезорівнях. По-перше, тактичні завдання передбачають пошук джерел максимізації прибутку, більш повного задоволення споживачів, ефективного та оптимального використання всіх видів ресурсів 3 одночасним впровадженням та адаптацією єдиного цифрового формату у виробничі, розподільчі та сервісні системи. По-друге, застосування нових інформаційних технологій при дослідженні, виборі схем розподілу потоків, визначенні оптимальної кількості та місць розташування розподільчих центрів, управлінні процесами проходження матеріальних потів на відповідних рівнях розповсюдження. По-третє, оптимізація планування видів упаковки, побудова оптимальних маршрутів доставки, прискорення роботи 3 замовленнями 3 паралельним введенням інфокомунікаційних технологій та штучного інтелекту на рівні підприємств.

Реалізація окреслених завдань маркетингової логістики супроводжується великою кількістю даних. Саме інформаційним даним властива мінливість запити та повідомлення споживачів можуть швидко змінюватись, інтенсивність звернень здатна коливатись, запити за типами даних інколи втрачають актуальність, швидкість передачі великих інформаційних масивів може мінятися та створювати «вузькі» місця. Постійне зростання обсягів інформації призводить до зниження пропускної спроможності логістичних каналів й загострення питань щодо визначення існуючого та потенційного попиту [2], [5], [7].

Інформаційну базу маркетингової логістичної системи формують паперові документи та електронні дані, такі як: товарні накладні, телефонограми і факси; відомості про надходження i розміщення вантажів на складах; дані про транспортні тарифи, маршрути, типи транспорту; зміни стану запасів; нормативно-довідкова виробнича інформація; дані про динаміку ринку, його сегментацію; відомості про виробничі потужності, постачальників і продуцентів; дані про зміни в динамічних моделях портфеля замовлень; відомості про незавершене виробництво, плани випуску; дані про склади, обсяги та види готової продукції; дані про фактичний збут продукції; відомості про фінансові потоки [6], [8].

Складна, багатопрофільна сукупність поточних даних, паперових документів, електронних звітів і медіазасобів стають підгрунтям для виникнення інтерактивних маркетингових i комерційних комунікацій в підприємницької 
діяльності. Нові способи накопичення та обробки інформації спрямовані на оптимізацію комунікативних можливостей. Це досягається за рахунок оперативного визначення каналів розподілу, продуктивного створення збутової мережі, гнучкого обслуговування цільового ринку та окремих сегментів. Сучасні інструменти інформаційного забезпечення орієнтовані на забезпечення відкритих інформаційних технологій, використання глобальних промислових мереж, накопичення актуальної інформації у рамках окремого підприємства та за його межами (рис.1).

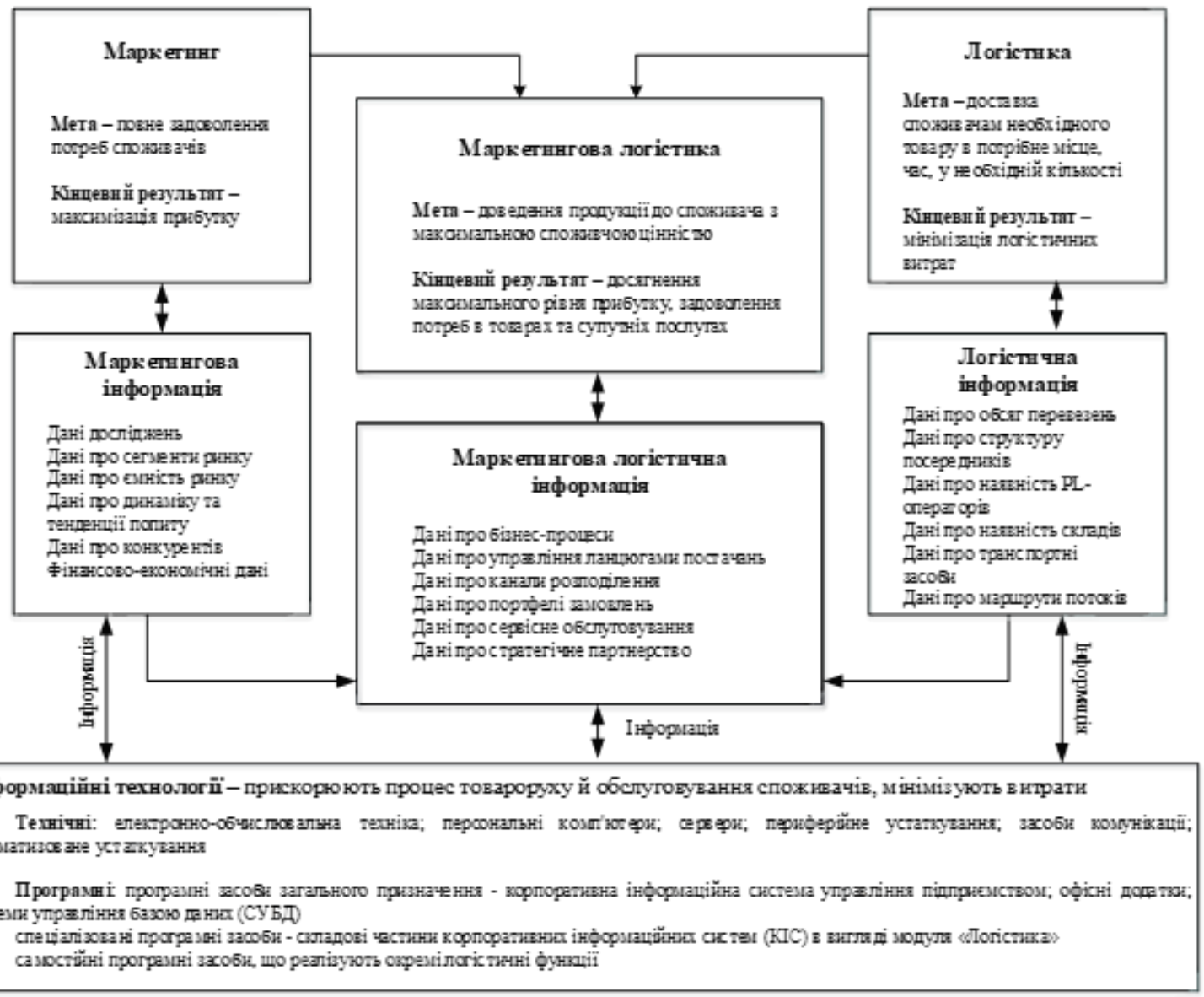

Рис. 1. Інформаційне забезпечення маркетингової логістики

У світовій практиці при формуванні логістичних каналів перевага віддається інформаційним системам заснованим на принципах індустрії 4.0 використання інтернету, інфокомунікаційних технологій (IКТ), стійких каналів зв'язку, хмарних технологій і цифрових платформ. Такі компоненти як інтернет речей, штучний інтелект, робототехніка, хмарні обчислення, Big Data, адитивне виробництво, моделювання, додаткова реальність, кібербезпека перетворюють загальноприйняті правила логістичного обслуговування й дозволяють автоматично приймати рішення у окремих бізнес-процесах [7], [9].

У межах індустрії 4.0 маркетингова логістика здатна виконувати важливу управлінську роль. Перетворюючись у єдину систему: «розробка - виробництво комунікації - розподіл - транспортування - сервіс - підтримка власних продуктів» досягається координація усіх видів діяльності. Такий взаємопов’язаний ланцюг спрямований на створення споживчої цінності при 
активному впровадженні інформаційних технологій нового покоління. Такі дій розширюють і перетворюють маркетингову логістику на якісно новий рівень: поперше, формується можливість використання найбільш зручного типу інформації (текстового, мультимедійного; графічного, аудіо-, відео-; інтерактивного); подруге, розповсюдження інформації стає більш швидким та необмеженим.

В дійсний час прогресивні світові фахівці 3 маркетингу та логістики використовують інформаційні технології засновані на WMS-системах управління складом, електронному обміні даними EDI, технологіях безконтактної ідентифікації визначення унікальності товару, технологіях радіочастотної автоматичної ідентифікації даних, супутниковій технології (GPS) контролю переміщення товарів, інтернет-технологіях [9]. Новітні можливості дозволяють швидко ідентифікувати та характеризувати стан речей, передавати та обробляти дані, мінімізувати рутинні рішення, виключати людський чинник 3 окремих бізнес-процесів (рис.2).
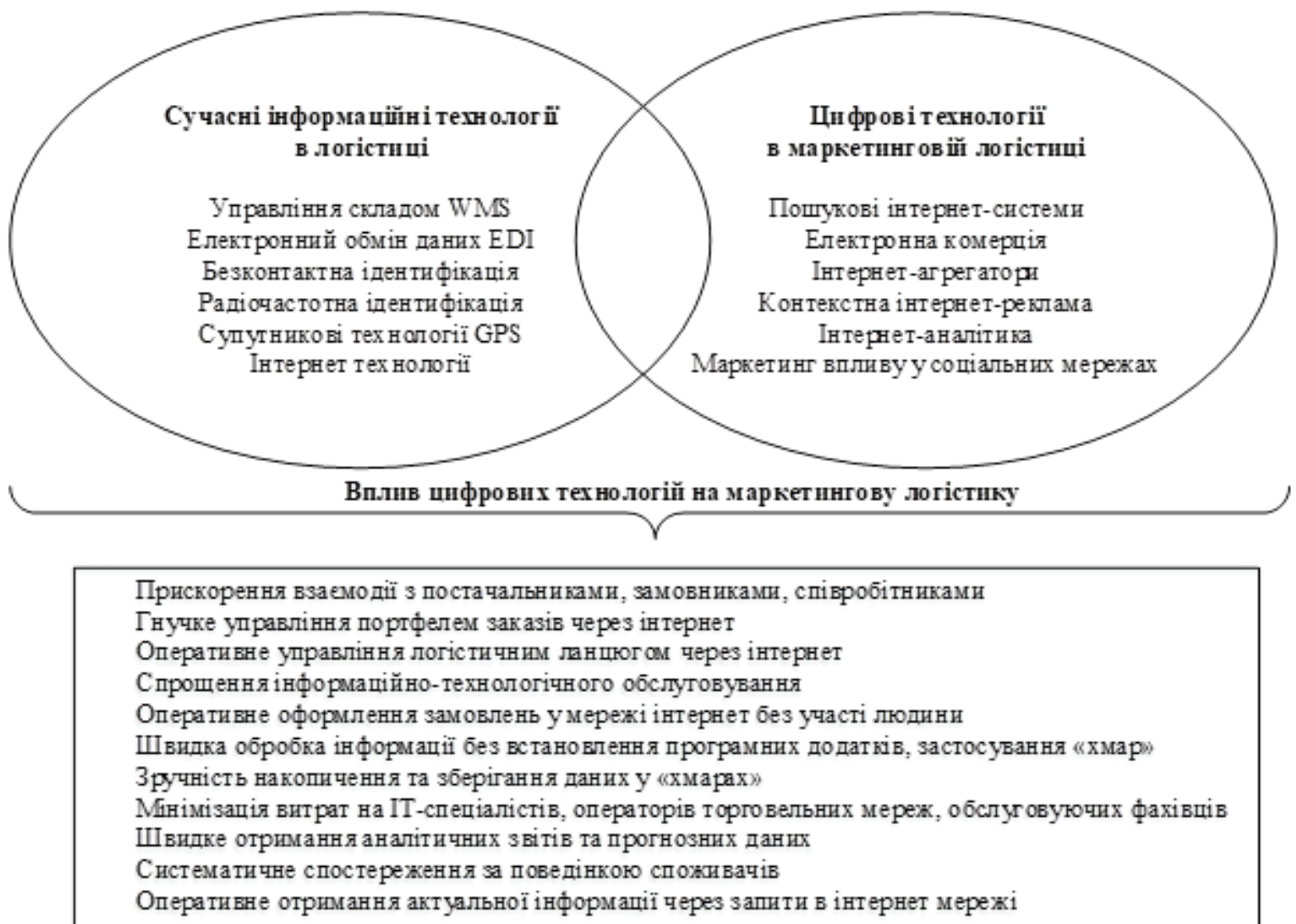

Рис. 2. Вплив інформаційних технологій на маркетингову логістику

Маркетингова логістика отримує більш автономні, швидкі, системні та контрольовані риси. У цифровому форматі мінімізуються витрати на підтримуючі процеси - інфраструктурне забезпечення, фінансове планування, управління людськими ресурсами, дослідження, просування, управління продуктом та ін.

Розвиток маркетингової логістики у цифровому форматі безпосередньо залежить від стану економічного розвитку країни та наявної державної підтримки бізнесу. В останні роки в Україні спостерігається зростання загальних обсягів виробництва деяких груп товарів, збільшуються обсяги внутрішньої оптової та 
роздрібної торгівлі. У свою чергу, зовнішньоекономічні показники характеризуються скороченням обсягів експорту та зниженням курсу національної валюти. Загальне зниження доходів учасників економічної діяльності призводить до мінімізації витрат, у тому числі за рахунок логістичних послуг [5].

Під впливом низки факторів формуються як позитивні так й негативні тенденції логістичного ринку України. Головними недоліками є вплив кризових явищ на перерозподіл частки вантажоперевезень між видами транспорту, зниження товарообігу, скорочення витрат на складські послуги. Незважаючи на важливість та перспективність логістичних послуг, транспортні потужності в Україні використовуються недостатньо, транспортна інфраструктура та рівень логістичних послуг є нижчими від стандартів країн $\mathrm{EC}$, витрати на логістику залишаються високими. Проте з 2017 р. простежується активізація торгівлі, що призвела до відновлення складського ринку, зростанню популярності торгівлі та обслуговування через інтернет-магазини [5]. Саме розвиток інтернет-торгівлі посприяв збільшенню попиту на послуги логістичних компаній у різних сегментах.

Аналіз тенденцій інфраструктурного розвитку національної економіки дозволяє виокремити низку проблем, що негативно впливають на впровадження досконалої системи маркетингової логістики, а саме:

відсутність єдиної сервісної платформи та мобільних додатків, що містять найвигідніші параметри перевезень, поєднують та спрощують взаємодію вантажовласників та підрядників;

ускладнення зберігання електронних даних і використання ліцензійних інформаційних технологій, через необхідність постійного оновлення та переустановлення, нестача досвіду системної роботи в хмарних технологіях;

відсутність досвіду комплексного стеження за вантажем, нестача даних про стан і статус вантажу у режимі реального часу, оскільки інформація про місцезнаходження транспорту, час прибуття, вибуття вантажу, наявність порожніх, переповнених складів вже не задовольняє клієнтів;

Розв'язання перелічених проблем можливо за умов впровадження досконалих підходів управління в системі маркетингової логістики, що відповідають вимогам ринку інформаційного типу. Отже стає доцільним:

глобальне розширення меж освоєння капіталу, виробництва, ринків збуту, створення стійких дистрибутивних, транспортно-логістичних, комунікаційних, та інформаційних систем;

постійне відстеження ринкових трендів і тенденцій, аналіз їх перспектив, адаптація до швидко мінливих умов ринкового середовища, забезпечення відповідності послуг до вимог споживача;

системне, комплексне та пропорційне інтегрування маркетингових i логістичних підсистем, їх системне координування;

впровадження новітніх технологій у бізнес-процеси, здатних до інтеграції 3 інформаційними системами та технологіями;

поширення інструментів інформатизації та комп'ютеризації, застосування комп'ютерно-комунікаційного супроводу.

Виконання перелічених заходів передбачає застосування інформаційних технологій на усіх стадіях бізнес-процесів. Впровадження інформаційних 
технологій здатне мінімізувати ймовірні помилки, збої, недопоставки тощо. Разом iз цим підвищується рівень обслуговування, якість виконання замовлень, сервісних послуг; забезпечуються умови договорів і стандарти обслуговування клієнтів.

Висновки $i$ перспективи подальших досліджень. Слід визначити, що світовий бізнес розглядає маркетингову логістику як ключовий елемент конкурентної ринкової стратегії. Сукупність положень про раціональне продуктове планування, оптимізацію інформаційних, матеріальних, транспортних, сервісних та інших потоків стає основою формування досконалого управління. Дослідження особливостей впливу сучасних інформаційних технологій на розвиток маркетингової логістики дозволило визначити, що за умов впровадження новітніх підходів управління сучасному бізнесу стають доступними:

удосконаленні системи управління взаємовідносинами 3 клієнтами, створені на основі актуальних даних про попит і поведінку споживачів й дієвих сервісних програмах;

формування ефективної системи розподілу товарів, оперативне планування логістичних операцій 3 урахуванням маркетингової політики обслуговування учасників каналу розподілу;

удосконаленні методи управління портфелем замовлень, основані на актуальних даних із різних ринкових сегментів;

розвиток системи прогнозування попиту на логістичний сервіс, побудова повного циклу обслуговування споживачів;

створення дієвої системи управління попитом, забезпечення високої споживчої цінності послуг на основі постійної взаємодії зі споживачами.

Розвинуті на засадах цифрового управління маркетингові та логістичні системи дозволяють мінімізувати втрати матеріальних, фінансових, трудових та інформаційних потоків, скоротити неузгодженість потоків заготівельної, виробничої та розподільчої логістики, удосконалити комплекс сервісних послуг. Практичне перетворення маркетингової логістики у новітній цифровий формат здатне призвести до чіткої ринкової орієнтації виробництва, збуту та конкурентних позицій на ринку.

\section{Лimepamypa:}

1. Гурська М. Всі говорять про штучний інтелект. Простими словами пояснимо, що це. URL: https://espreso.tv/article/2017/11/04/shtuchnyy_intelekt

2. Длігач А. Тенденції розвитку маркетингу в Україні. Маркетинг в Україні. 2005. № 1. С. 35-38.

3. Котлер Ф. Маркетинг менеджмент [пер. с англ.]. 11-е изд.; СПб.: Питер, 2005. 800 с.

4. Економіка логістики: навч. посібник / За ред. Є.В. Крикавського, О.А. Похильченко. Львів: Видавництво Львівської політехніки, 2014. 640 с.

5. Особливості ринку логістичних послуг в Україні. Інформаційний дайджест. URL: https://pro-consulting.ua/ua/pressroom/osobennosti-rynkalogisticheskih-uslug-v-ukraine. 
6. Плахута Г.А. Інтеграція маркетингу i логістики в системі менеджменту. Маркетинг: теорія і практика: зб. наук. Праць Східноукраїнського національного університету імені Володимира Даля. 2008. Вип. 14. С. 145-148.

7. Скіцько В.І. Логістика в Індустрії 4.0. Економіка та держава. 2016. № 4. C. 28-33. URL: http://www.economy.in.ua/pdf/4_2016/7.pdf

8. Скіцько B.I. Концептуальні засади управління логістичними системами 3 врахуванням синергії та синергетики. Вісник Київського національного університету імені Тараса Шевченка. Економіка. 2015. Вип. 4. C. 53-58.

9. Digital Technology. URL: http://technologyin.org/digital-technology

10. Buxton Graham. Effective marketing logistics: the analysis planning and control of distribution operations. Holmes \& Meier Publishers, Inc., 1975. 244 p.

11. Christopher M. Marketing Logistics. H. Peck. Second Edition. Oxford: Elsevier Butterworth-Heinemann, 2003. 168 p.

\section{References:}

1. Ghursjka M. Vsi ghovorjatj pro shtuchnyj intelekt. Prostymy slovamy pojasnymo, shho ce. URL: https://espreso.tv/article/2017/11/04/shtuchnyy_intelekt.

2. Dlighach A. Tendenciji rozvytku marketynghu v Ukrajini. Marketyngh $v$ Ukrajini. 2005. \# 1. S. 35-38.

3. Kotler F. Marketyngh menedzhment [per. s anghl.]. 11-e yzd.; SPb.: Pyter, $2005.800 \mathrm{~s}$.

4. Ekonomika loghistyky: navch. posibnyk / Za red. Je.V. Krykavsjkogho, O.A. Pokhyljchenko. Ljviv: Vydavnyctvo Ljvivsjkoji politekhniky, 2014. $640 \mathrm{~s}$.

5. Osoblyvosti rynku loghistychnykh poslugh $\mathrm{v}$ Ukrajini. Informacijnyj dajdzhest. URL: https://pro-consulting.ua/ua/pressroom/osobennosti-rynkalogisticheskih-uslug-v-ukraine.

6. Plakhuta Gh.A. Integhracija marketynghu i loghistyky v systemi menedzhmentu. Marketyngh: teorija i praktyka: zb. nauk. Pracj Skhidnoukrajinsjkogho nacionaljnogho universytetu imeni Volodymyra Dalja. 2008. Vyp. 14. S. 145-148.

7. Skicjko V.I. Loghistyka v Industriji 4.0. Ekonomika ta derzhava. 2016. \# 4. S. 28-33. URL: http://www.economy.in.ua/pdf/4_2016/7.pdf

8. Skicjko V.I. Konceptualjni zasady upravlinnja loghistychnymy systemamy z vrakhuvannjam synerghiji ta synerghetyky. Visnyk Kyjivsjkogho nacionaljnogho universytetu imeni Tarasa Shevchenka. Ekonomika. 2015. Vyp. 4. S. 53-58.

9. Digital Technology (2019) [Online], available at: http://technologyin.org/digital-technology (accessed (10.06.19))

10. Buxton Graham (1975) Effective marketing logistics: the analysis planning and control of distribution operations, Holmes \& Meier Publishers, Inc., 244 p.

11. Christopher M. (2003) Marketing Logistics, Second Edition. - Oxford: Elsevier Butterworth-Heinemann, 168 p.

The article substantiates the relevance of the topic under study, shows the features of modern business in the context of the development of Internet services and the expansion of commercial operations in digital mode. The features of the integration of 
intermediary companies and PL-providers that have increased the role of marketing and logistics services in the development of market infrastructure have been studies.

The features of the emergence of new organizational and functional tasks in the marketing logistics system are reveal. New requirements for building a management system was identify: ensuring the integrated interaction of management systems, optimization and integration of information system components, expansion and deepening of specialization, improvement of interaction between marketing and logistics systems.

There are listed the information technologies used in world practice: WMSwarehouse management systems, electronic data interchange EDI, contactless identification technology, product unique identification technology, radio frequency automatic data identification technology, satellite technology (GPS) control of goods movement, Internet technology. The possibilities of digital technologies are reveal: rapid identification of the state of affairs, prompt transfer and processing of data, minimization of routine decisions and the human factor in separate business processes.

The features of the development of marketing logistics in the conditions of the Ukrainian economy are investigate. The features of the digitalization of business in Ukraine are studied. Analysis of trends in infrastructure development allowed us to determine the level of development of marketing logistics. It was determined that now: there is no single platform and mobile applications. Which contain favorable parameters of transportation and maintenance, the system of data storage and maintenance becomes complicated, cloud technologies are not use on a large scale, and there is not enough experience in monitoring the status of orders, cargo movement and transport in real time. The prospects for the development of marketing logistics in the digital economy are determined. 